Chirurgia (2018) 113: 101-107

No. 1, January - February

Copyright@ Celsius

http://dx.doi.org/10.21614/chirurgia.113.1.101

\title{
Gastroesophageal Reflux Before Metabolic Surgery
}

\author{
Ionuț Hutopilă, A. Constantin, Cătălin Copăescu
}

Ponderas Academic Hospital, Bucharest, Romania

Corresponding author:

Catalin Copaescu, MD PhD

Associated Professor of Surgery

Head of Minimal Invasive and Metabolic

Surgery Department

Director of the Bariatric \& Metabolic

Surgery Program

Bariatric Center of Excellence IFSO

EAC-EC and SRC International Center

of Excellence

Ponderas Hospital, Bucharest, Romania

E-mail: catalincopaescu@gmail.com
Received: 03.01.2018 Accepted: 08.02.2018

\section{Rezumat}

\section{Refluxul gastroesofagian înainte de operatia metabolică}

Introducere: Prevalența obezității a crescut semnificativ în ultimele decenii, iar chirurgia metabolică (bariatrică) a fost extinsă în consecință. Manifestările clinice ale bolii de reflux gastroesofagian (BRGE) sunt frecvente la populația obeză, dar prezența semnelor sau complicaților BRGE la pacienții asimptomatici supuşi unei intervenții chirurgicale metabolice este neclară.

Obiective: (1) identificarea refluxului gastroesofagian sau a complicațiilor acestuia la pacienții supuşi unei intervenții chirurgicale metabolice. (2) Studierea corelatiilor simptomelor clinice ale BRGE cu constatările radiologice şi endoscopice preoperatorii.

Metoda: Toți pacienții consecutivi (BRGE simptomatici sau nu) candidati pentru o intervenție chirurgicală metabolică într-un centru de excelență Bariatric între decembrie 2015 şi mai 2016 au fost incluşi într-un studiu prospectiv. $\mathrm{O}$ echipă multidisciplinară a evaluat toți pacienții din cadrul programului de chirurgie bariatrică. Evaluarea clinică, investigațiile radiologice şi endoscopice au fost efectuate la toți pacienții incluşi. Pacienții care au avut anterior un tratament anti-reflux sau bariatric au fost excluşi.

Rezultate: Patru sute patruzeci şi opt de pacienți consecutivi au fost înscrişi în studiu. Vârsta medie a pacienților a fost de $41,04( \pm 11,15)$ ani, iar 29\% dintre aceştia au fost bărbați. Valoarea medie a IMC a fost de 39,96 $( \pm 8,17) \mathrm{kg} / \mathrm{m}^{2}$. Simptome BRGE au fost înregistrate numai la 93 pacienți $(20,76 \%)$, în timp ce examinarea endoscopică a evidențiat esofagită la $139(31,03 \%)$ pacienți (107 grade A, 28 grade B, 3 grade C, 1 grad D). Esofagul Barrett a fost suspectat la 5 pacienți, dar confirmarea histologică (metaplazia gastrică) a fost înregistrată numai la 2 pacienți $(0,44 \%)$. Hernia hiatală a fost descoperită prin endoscopie şi radiologie la $119(26,56 \%)$ şi 112 
pacienți (25\%). 62\% dintre pacienții care prezentau esofagită (86/139) nu au avut nici un simptom preoperator al BRGE, ceea ce înseamnă că un număr semnificativ de pacienți asimptomatici supuşi unei intervenții chirurgicale metabolice pot prezenta consecințe ale refluxului gastro-esofagian.

Concluzii: Studiul demonstrează că BRGE este mai frecventă decât se aşteaptă la pacienții obezi asimptomatici supuşi unei intervenții chirurgicale metabolice. Impactul clinic al acestor constatări este important pentru selectarea corectă a procedurii şi pentru o evaluare corectă a evoluției postoperatorii.

Cuvinte cheie: reflux gastroesofagian, endoscopie preoperatorie, chirurgie bariatrica, esofag Barrett

\section{Abstract}

Background: Obesity has significantly increased in the last decades and metabolic (bariatric) surgery has been extended accordingly. Clinical manifestations of Gastroesophageal reflux disease (GERD) are frequent in the obese population but the presence of GERD premises (i.e. Hiatala hernia) or complications in asymptomatic patients undergoing metabolic surgery is unclear.

Aim: (1) to identify gastroesophageal reflux condition or complications in patients undergoing metabolic surgery. (2) Study the correlations of the clinical symptoms of GERD with the preoperative radiological and endoscopic findings.

Methods: All the consecutive patients (GERD symptomatic or not) undergoing metabolic surgery in a Bariatric Center of Excellence between December, 2015 and May 2016 were included in a prospective study. A multidisciplinary team evaluated all the patients within the bariatric surgery program. Clinical evaluation, radiological and endoscopic investigations were performed to all the included patients. The patients who previously had anti-reflux or bariatric surgery were excluded.

Results: Four-hundred-forty-eight consecutive patients were enrolled into the study. The mean age of patients was $41.04( \pm 11.15)$ years, and $29 \%$ of them were men. The mean BMI was $39.96( \pm 8.17) \mathrm{kg} / \mathrm{m}^{2}$. Symptoms of GERD were recorded only in 93 of the patients $(20.76 \%)$ while endoscopic examination revealed esophagitis in 139 (31,03\%) patients (107 Grade A, 28 Grade B, 3 Grade C, 1 Grade D. Barrett esophagus was suspected in 5 patients but histologic confirmation (gastric metaplasia) was recorded only in 2 patients (0.44\%). Hiatal hernia was revealed by endoscopy and radiology in $119(26,56 \%)$ and 112 patients $(25 \%) .62 \%$ of the patients presenting esophagitis (86/139) had no pre-operative symptom of GERD, meaning that a significant number of the asymptomatic patients undergoing metabolic surgery may present consequences of gastro-esophageal reflux.

Conclusions: The study demonstrates that GERD is more frequent then expected in asymptomatic obese patients undergoing metabolic surgery. The clinical impact of these findings is important for the proper procedure selection and for a correct evaluation of the postoperative evolution.

Key words: gastro-esophageal reflux, preoperative endoscopy, bariatric surgery, Barrett esophagus

\section{Introduction}

The prevalence of gastroesophageal reflux disease in the general population is between $5 \%$ and $20 \%(1,2)$. Overweight and obesity are recognized as important risk factors for gastroesophageal reflux disease (GERD) (3).
Consequently, in the last decades, the considerable increase in the number of people with obesity was followed by the more frequent reporting of gastroesophageal reflux disease. Along with patients who are addressing the physician, due to the presence of typical symptoms (retrosternal heartburn, regurgitation, 
epigastric pain), a significant number of obesity patients have premise or consequences of GERD outside of clinical manifestations (patients with asymptomatic reflux). This situation can be explained by the fact that obesity generates a particular situation by altering the sensitivity and diminishing the esophageal symptoms $(4,5)$. Therefore, there was no correlation between clinical signs and the presence of imaging or endoscopic changes, a circumstance that may cause underestimation of the prevalence of GERD in obese patients (5). On the other hand, in the context of epidemic obesity, we find a significant increase in the use of metabolic surgery, especially of laparoscopic gastric sleeve (LSG) procedures (6), and the influence of these operations on GERD is of concern and a lot of debate in literature (7-11). Consequently, preoperative extensive evaluation of GERD in bariatric patients is mandatory for establishing surgical treatment (type of metabolic surgery, hiatal hernia repair), but also for accurate reporting of BRGE progression following such operations and postoperative weight loss. This will create the premises for correct assignments of the remissions, as well as the "de novo" incidence of GERD.

\section{Aim}

The objectives of this study are:

1. Identification of GERD in candidates for metabolic treatments.

2. Analysis of correlation of symptomatology with preoperative radiological and endoscopic aspects in these patients.

\section{Material and Methods}

The study looks prospectively for consecutive patients, with or without BRGE symptomatology, evaluated for the treatment of obesity by endoscopic or surgical bariatric procedures (regardless of the type of surgery subsequently established). This study was conducted between December 2015 and May 2016 at the Ponderas Academic Hospital - Center of Excellence in Bariatric and Metabolic Surgery. All patients were investigated by a multidisciplinary team according to a protocol implemented in the bariatric surgery program that provided data obtained from: clinical examination, symptomatology, medical history, treatments, laboratory analysis, oral contrast study, upper digestive endoscopy, 24-hour pH monitoring. Patients who had a medical history of bariatric surgery or antireflux, endoscopic or surgical procedures were excluded from the study.

\section{Clinical and Anamnestic Data}

Symptoms characteristic of reflux disease have been reported: heartburn, regurgitation, epigastric pain, dysphagia as well as the existence and therapeutic effects of acid reflux medication (when appropriate).

\section{Oral Contrast Study}

For each patient was noted the presence of radiological signs of GERD and the identification of radiographic signs of hiatal hernia. The device used was Siemens Luminos Fusion - Fluorospot Compact (Siemens Healthcare GmbH, Erlangen, Germany).

\section{Upper Gastrointestinal}

Upper gastrointestinal endoscopy recorded the presence of esophagitis and its staging was made after the Los Angeles classification (12); It was also noted the presence of hiatal hernia, Barrett's esophagus and other esogastroduodenal changes identified during these explorations. The biopsy was performed in all cases of metaplasia. The investigation was performed under i.v. sedation with midazolam using the Olympus Exera III system.

\section{4-h Impedance $\mathrm{pH}$ Monitoring}

24-h impedance $\mathrm{pH}$ monitoring - has been performed selectively only in patients who have identified suggestive changes for the Barrett esophagus. Catheter with $1 \mathrm{pH}$ sensor placed above the upper LES edge according to catheter variation $\mathrm{ph}$ and 6 impedance sensors (placed at 3, 5, 7, 9, 15, $17 \mathrm{~cm}$ towards the upper edge of LES), (Given Imaging, Medtronic, U.S.).

All the data has been introduced in Excel Microsoft Office 2016, vs 1801, Microsoft 
Corporation. Statistical analyses were carried out by SAS University Edition v 9.2, (c) SAS Institute Inc. 100 SAS Campus Drive Cary, NC 27513-2414, USA. The data are presented in Average Arithmetic ( \pm D.S $)$ D.S. = standard deviation for continuous variables and absolute frequency and relative frequency for the category variables. A P-value lower than 0.05 was considered to be statistically significant.

Information regarding the study was provided to the patients and their written informed consents were taken in accordance with the Helsinki Declaration. The hospital ethics committee approved the study.

\section{Results}

Four-hundred-forty-eight consecutive patients were enrolled into the study between December, 2015 and May, 2016. The mean age of patients was $41.04( \pm 11.15)$ years, and $29 \%$ of them were men (m/f: 134/314). The mean patients' weight and abdominal circumference was 115.82 $( \pm 28.82) \mathrm{kg}$ and $121.45(19.20) \mathrm{cm}$, while the mean BMI was $39.96( \pm 8.17) \mathrm{kg} / \mathrm{m}^{2}$. As expected, comorbidities were found in a significant number of the patients: hypertension $33,48 \%$, Type2 Diabetes mellitus 14,95\%, Dyslipidemia $56,3 \%$ and OSA in $10,93 \%$ of the patients. 183 patients were smokers (Table 1).

Typical symptoms of GERD were recorded only in 93 of the patients $(20.76 \%)$ and only five of them were on PPI therapy, while the rest of the patients $(79.24 \%)$ had no reflux complain. Endoscopic examination revealed esophagitis in $139(31,03 \%)$ patients (107 Grade A, 28 Grade B, 3 Grade C, 1 Grade D). Barrett with histologic confirmation (gastric metaplasia) was recorded in 2 patients $(0.44 \%)$. Endoscopy demonstrated hiatal hernia in 119 of the patients (26,56\%). Upper GI radiological study revealed gastro-esophageal reflux in 163 the patients $(36.38 \%)$, and radiological signs of hiatal hernia were noticed in 112 patients (25\%) (Table 2).

The results showed the presence of esophagitis in a significant number of the asymptomatic patients, with an increase of more than $50 \%$ of the cohort affected by GERD
Table 1. Demographic characteristics of the patients

\begin{tabular}{lc}
\hline Age & $41.04( \pm 11.15)$ \\
\hline Gender & $134 / 448(29.91)$ \\
M / Total (\%) & $314 / 448(70.09)$ \\
F / Total (\%) & $115.82( \pm 28.82)$ \\
Weight av. (kg) & $121.45(19.20)$ \\
\hline Abdominal circumference (cm) & \\
\hline Comorbidity & $150 / 448(33.48)$ \\
$\quad$ Hypertension & $67 / 448(14.95)$ \\
Diabetes type II & $251 / 448(56.03)$ \\
Dyslipidemia & $49 / 448(10.93)$ \\
Obstructive Sleep Apnea (OSA) & $183 / 448(40.85)$ \\
\hline Smoking &
\end{tabular}

within the group of the patients undergoing metabolic surgery $(20.76 \%$ vs $31.3 \%)$. For the patients with endoscopic findings of esophagitis (139 pts), we found a significant correlation with the GERD clinical symptoms, the presence of hiatal hernia (endoscopy and radiology) and the contrast gastroesophageal reflux (Table 3). More interesting was to discover that $62 \%$ of the patients presenting esophagitis (86/139) had no preoperative symptom of GERD, meaning that a significant number of the patients undergoing metabolic surgery may present consequences of gastro-esophageal reflux (Graphic 1).

We demonstrated that gastroesophageal reflux may significantly occur even in asympto-

Table 2. GERD symptoms, endoscopic and radiological findings in the preoperative investigations of metabolic patients

\begin{tabular}{lc}
\hline Symptoms & \\
\hline $\begin{array}{l}\text { Heartburn, regurgitation, epigastric pain } \\
\text { (5 patients on IPPS) }\end{array}$ & $93 / 448(20.76 \%)$ \\
\hline $\begin{array}{l}\text { Endoscopy } \\
\quad \text { Esophagitis }\end{array}$ & $139 / 448(31.03 \%)$ \\
\hline $\begin{array}{l}\text { Los Angeles A esophagitis } \\
\text { Los Angeles B esophagitis }\end{array}$ & $107 / 448(23.88 \%)$ \\
\hline $\begin{array}{l}\text { Los Angeles C esophagitis } \\
\text { Los Angeles D esophagitis }\end{array}$ & $28 / 448(6.42 \%)$ \\
\hline $\begin{array}{l}\text { Barrett with histologic confirmation } \\
\text { (gastric metaplasia) } \\
\quad \text { Hiatal hernia }\end{array}$ & $3 / 448(0.6 \%)$ \\
\hline $\begin{array}{l}\text { Radiological aspects } \\
\text { GE reflux }\end{array}$ & $1 / 448(0.2 \%)$ \\
$\quad$ Hiatal Hernia & $2 / 448(0.44 \%)$ \\
\hline
\end{tabular}


Table 3. Correlations between esophagitis Symptoms, Weight, BMI, Abdominal Circumference, Smoking, Type 2 DM, radiological signs of hiatal hernia, reflux and endoscopic relevance of hiatal hernia

\begin{tabular}{ccccccccccc}
\hline \multicolumn{10}{c}{$\begin{array}{c}\text { Spearman's correlation coefficient } \\
\text { P-value } \\
\text { Number of cases }\end{array}$} \\
\hline & Symptoms & Weight & BMI & Abd. circ. & Smoking & DZ II & RX Reflux & RX HH & HH endoscopy \\
\hline Esophagitis & 0.28725 & 0.12903 & 0.09539 & 0.09947 & 0.07088 & 0.00224 & 0.36533 & 0.22363 & 0.26239 \\
& $<.0001$ & 0.0062 & 0.0436 & 0.0353 & 0.1341 & 0.9623 & $<.0001$ & $<.0001$ & $<.0001$ \\
& 448 & 448 & 448 & 448 & 448 & 447 & 448 & 445 & 447 \\
\hline
\end{tabular}

matic obese patients undergoing metabolic surgery. Therefore, patients should be carefully evaluated before surgery even in the absence of symptoms. The clinical impact of these findings is very important for the candidates to metabolic surgery in order to select the proper procedure and have a correct evaluation of the postoperative evolution.

\section{Discussions}

Obesity is often associated with gastroesophageal reflux disease (GERD) and hiatal hernia $(\mathrm{HH})(13,14)$. Pathophysiology includes several mechanisms. In the obesity-GERD relationship, both anatomical and hormonal changes are caused by fat excess. The link between obesity and GERD is direct through increased weight, but especially through the distribution of adipose tissue. Thus patients

\section{Patients presentig esophagitis}

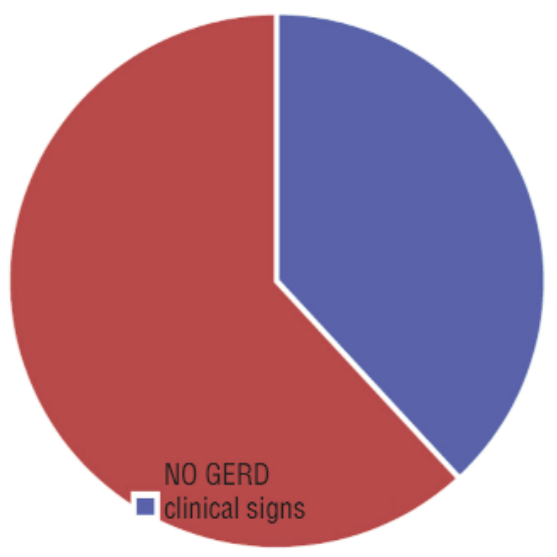

Graphic 1. Correlations between esophagitis and GERD symptoms in patients undergoing metabolic surgery. with abdominal obesity have a higher risk of developing gastro-oesophageal reflux $(15,16)$. In our study we confirm a positive correlation between the GERD and weight, BMI and abdominal circumference. This also happens as a result of the increase (table 3 ) in intraabdominal pressure which will lead to changes of the anatomical elements of the gastroesophageal junction, resulting in the occurrence of hiatal hernias much more frequently than in the normoponderal population $(17,18)$. Once the phrenoesophageal membrane is thinned, the intraabdominal pressure will move the lower esophageal sphincter (LES) towards the mediastinum, making it incompetent and allowing acid reflux at the terminal esophagus. Esophageal motility disorders (LES malfunction and / or inappropriate body activity of the esophagus) are part of the mechanisms for producing GERD irrespective of body weight, but in the case of obese patients these are found in $61 \%$ of them (19). This finding is based on the hypothesis that leptin is a hormone synthesized mainly by adipocytes, is found in larger amounts in obese people and could cause hypomotility of the gastrointestinal tract $(20,21)$. One of the main factors involved in the occurrence of GERD in obese patients is the increase in the frequency of transient relaxation of LES, achieved by mechanical stimulation by distention of the gastric fundus, but also by activation of chemoreceptors at the junction of the gastro-esophageal junction and the proximal portion of the stomach. The way in which patients with obesity (often compulsive and with high volume of food) are eating, is the one that can lead to increased postgrandial intragastric pressure, with more frequent 
relaxation of LES and, implicitly, the onset of GERD (22). In addition to these particular mechanisms, there are also independent weight factors such as smoking, alcohol consumption, food preferences like as a high fat diet, and how these patients are feeding. Poor weight control, including the mechanisms involved, causes the evolution of reflux disease to complicated forms such as erosive esophagitis, Barrett's esophagus or even esophageal adenocarcinoma. Barrett's esophagus has been reported at a 3 -fold higher frequency than in the normoponderal population $(23,24,25)$, but in our group we met it in only 2 cases $(0.44 \%)$. The characteristic symptoms of GERD (heartburn, regurgitation, epigastric pain, dysphagia) are described in other studies varying from $22 \%$ to $70 \%$ of obese patients (26); we recorded a lower percentage of symptomatic patients, around 20\%. A large number of obese patients addressing bariatric and metabolic surgery centers have no esogastric symptoms at the time of the investigations. This discordance between symptomatology and the proven existence of GERD is based on the hypothesis that obese patients have impaired visceral sensitivity. The increased percentage of fatty tissue in the human body results in decreased sympathetic and parasympathetic autonomic nervous system function, resulting in altered esophageal sensitivity transmitted vagal and decreased esophageal symptoms. In our study $62 \%$ of the patients with endoscopically diagnosed esophagitis had no preoperative symptoms of GERD. In this situation, guiding diagnosis according to the Montreal Consensus rules suggesting that GERD should be investigated only in the presence of symptoms that affect quality of life may lead to omission of a significant proportion of asymptomatic patients with gastro-oesophageal reflux. Therefore, for obese patients who will benefit from bariatric surgery, preoperative assessment of the esogastric function should be performed independently of the presence or absence of GERD symptoms, each patient should be evaluated according to a protocol including the eso-gastro-duodenal radiology study, superior digestive endoscopy or 24-h $\mathrm{pH}$ monitoring. The adequate preoperative identification of GERD with or without hiatal hernia in these patients is very important as it guides the surgeon in choosing the optimal type of bariatric surgery. Considering that obesity can cause GERD, ideal surgical treatment should control both body weight and gastric reflux (27). Roux - en -Y Gastric bypass follows these two mandatory requirements (28). Bariatric surgery is the most effective method of weight-loss and long-term maintenance, reducing comorbidities associated with obesity, and acting better on GERD mechanisms than strictly anti-reflux procedures (Nissen, Toupet, Dor fundoplications) (29).

Limitatios of study: 24-h impedance-pH monitoring was used only for the patients with the endoscopic suspicion of Barrett (5 patients) and only in 2 of them had significant reflux (DeMeester score >14) and histological confirmation (gastric metaplasia). We consider that the absence of the 24-h impedance-pH monitoring in all the patients as the main limitation of the present study. However, the study enrolled a significant group of patients consecutively operated within six months in a Bariatric Center of Excellence.

\section{Conclusions}

$20 \%$ of the candidates for metabolic surgery reported typical GERD symptoms while one third had endoscopic and radiologic evidence of GERD. $62 \%$ of the patients with esophagitis were asymptomatic prior to surgery. Since typical reflux symptoms are not able to predict objective findings, endoscopy and radiologic investigations should be a must component of the preoperative work-up before metabolic procedures.

The study demonstrates that GERD is more frequent then expected in asymptomatic obese patients undergoing metabolic surgery. The clinical impact of these findings is important for the proper procedure selection and have a correct evaluation of the postoperative evolution. 


\section{Conflict of Interest}

No conflict of interest for any of the authors.

\section{References}

1. Katz PO, Gerson LB, Vela MF. Guidelines for the diagnosis and management of gastroesophageal reflux disease. Am J Gastroenterol. 2013;108(3):308-28; quiz 329. doi: 10.1038/ajg.2012.444. Epub 2013 Feb 19.

2. Nadaleto BF, Herbella FAM, Patti MG. Gastroesophageal reflux disease in the obese: Pathophysiology and treatment. Surgery. 2016;159(2): 475-86. doi: 10.1016/j.surg.2015.04.034. Epub 2015 Jun 6.

3. Richter JE, Rubenstein JH. Presentation and Epidemiology of Gastroesophageal Reflux Disease. Gastroenterology. 2018;154(2): 267-76. doi: 10.1053/j.gastro.2017.07.045. Epub 2017 Aug 3.

4. Hong D, Kamath M, Wang S, Tabet J, Tougas G, Anvari M. Assessment of the afferent vagal nerve in patients with gastroesophageal reflux. Surg Endosc. 2002;16(7):1042-5. Epub 2002 Apr 9.

5. Heimgartner B, Herzig M, Borbély $Y$, Kröll D, Nett P, Tutuian R. Symptoms, endoscopic findings and reflux monitoring results in candidates for bariatric surgery. Dig Liver Dis. 2017;49(7):750756. doi: 10.1016/j.dld.2017.01.165. Epub 2017 Feb 3.

6. Angrisani L, Santonicola A, lovino P, Vitiello A, Zundel N, Buchwald $\mathrm{H}$, et al. Bariatric Surgery and Endoluminal Procedures: IFSO Worldwide Survey 2014. Obes Surg. 2017;27(9):2279-2289. doi: 10.1007/s11695-017-2666-X.

7. Coupaye M, Gorbatchef C, Calabrese D, Sami O, Msika S, Coffin B, et al. Gastroesophageal Reflux After Sleeve Gastrectomy: a Prospective Mechanistic Study. Obes Surg. 2018 Mar;28(3):838-45. doi: 10.1007/ s11695-017-2942-9.

8. Page PL, Martin D, Taylor C, Wang J, Wadhawan H, Falk G, et al. Does hiatal repair affect gastroesophageal reflux symptoms in patients undergoing laparoscopic sleeve gastrectomy? Surg Endosc. 2017 Dec 12. doi: 10.1007/s00464-017-5935-9. [Epub ahead of print]

9. Salama A, Saafan T, El Ansari W, Karam M, Bashah M. Is Routine Preoperative Esophagogastroduodenscopy Screening Necessary Prior to Laparoscopic Sleeve Gastrectomy? Review of 1555 Cases and Comparison with Current Literature. Obes Surg. 2018;28(1):52-60. doi: 10.1007/s11695-017-2813-4.

10. Versteegden DPA, Van Himbeeck MJJ, Nienhuijs SW. Improvement in quality of life after bariatric surgery: sleeve versus bypass. Surgery for obesity and related diseases: official journal of the American Society for Bariatric Surgery. 2018;14(2):170-4.

11. Viscido G, Gorodner V, Signorini F, Navarro L, Obeide L, Moser F. Laparoscopic Sleeve Gastrectomy: Endoscopic Findings and Gastroesophageal Reflux Symptoms at 18-Month Follow-Up. Journal of laparoendoscopic \& advanced surgical techniques Part A. 2018;28(1):71-7.

12. Armstrong D, Bennett JR, Blum AL, Dent J, De Dombal FT, Galmiche JP, et al. The endoscopic assessment of esophagitis: A progress report on observer agreement. Gastroenterology.111(1):85-92.

13. Buchwald H, Cowan G, Pories W. Surgical management of obesity. Elsevier Inc. (US); 2007.

14. Wienbeck M, Barnert J. Epidemiology of reflux disease and reflux esophagitis. Scand J Gastroenterol 1989 (Suppl 156):7-13.

15. Nam SY, Choi IJ, Ryu KH, Park BJ, Kim HB, Nam BH. Abdominal visceral adipose tissue volume is associated with increased risk of erosive esophagitis inmen and women. Gastroenterology. 2010; 139(6):1902-1911.e2. doi: 10.1053/j.gastro.2010.08.019. Epub 2010 Aug 19.

16. Singh S, Sharma AN, Murad MH, Buttar NS, El-Serag HB, Katzka DA, et al. Central adiposity is associated with increased risk of esophageal inflammation, metaplasia and adenocarcinoma: a sistematyc review and meta-analysis. Clin Gastroenterol Hepatol. 2013;11(11):13991412.e7. doi: 10.1016/j.cgh.2013.05.009. Epub 2013 May 22.

17. Wilson LJ, Ma W, Hirschowitz BI. Association of obesity with hiatal hernia and esophagitis. Am J Gastroenterol. 1999;94(10):2840-4.

18. Suter M, Dorta G, Giusti V, Calmes JM. Gastroesophaeal reflux and esophageal motility disorders in morbidly obese patients. Obes Surg. 2004;14(7):959-66.

19. Jaffin BW, Knoepflmacher P, Greenstein R. High prevalence of asymptomatic esophageal motility disorders among morbidly obese patients. Obes Surg. 1999:9(4):390-5.

20. Côté-Daigneault J, Leclerc P, Joubert J, Bouin M. High prevalence of esophageal dysmotility in asymptomatic obese patients. Can J Gastroenterol Hepatol. 2014;28(6):311-4.

21. Yarandi SS, Hebbar G, Sauer CG, Cole CR, Ziegler TR. Diverse roles of leptin in the gastrointestinal tract: modulation of motility, absorption, growth, and inflammation. Nutrition. 2011;27(3):269-75. doi: 10.1016/j.nut.2010.07.004. Epub 2010 Oct 13.

22. Schneider JH, Küper M, Königsrainer A, Brücher B. Transient lower esophageal sphincter relaxation in morbid obesity. Obes Surg. 2009;19(5):595-600. doi: 10.1007/s11695-009-9809-7.

23. Koppman JS, Poggi L, Szomstein S, Ukleja A, Botoman A, Rosenthal R. Esophageal motility disorders in morbidly obese population. Surg Endosc. 2007;21(5):761-4. Epub 2007 Feb 7.

24. Friedenberg FK, Xanthopoulos M, Foster GD, Richter JE. The association between gastroesophageal reflux disease and obesity. Am J Gastroenterol. 2008;103(8):2111-22. doi: 10.1111/j.1572-0241. 2008.01946.x.

25. Varela JE, Hinojosa MW, Nguyen NT. Laparoscopic fundoplication compared with laparoscopic gastric bypass in morbidly obese patients with gastroesophageal reflux disease. Surg Obes Relat Dis. 2009;5(2):139-43. doi: 10.1016/.soard.2008.08.021. Epub 2008 Sep 4.

26. Braghetto I, Korn O, Csendes A, Gutiérrez L, Valladares H, Chacon M. Laparoscopic treatment of obese patients with gastro-esophageal reflux disease and Barrett's esophagus: a prospective study. Obes Surg. 2012;22(5):764-72. doi: 10.1007/s11695-011-0531-x.

27. Fisichella PM. The puzzling argument of antireflux surgery in obese patients with gastroesophageal reflux disease: can the excellent perioperative safety of antireflux surgery make up for better comprehensive long-term outcomes of bariatric surgery? Am J Surg. 2014;208(2):169-70. doi: 10.1016/j.amjsurg.2014.03.001. Epub 2014 Apr 24.

28. Pallati PK, Shaligram A, Shostrom VK, Oleynikov D, McBride CL, Goede MR. Improvement in gastro-esophageal reflux disease symptoms after various bariatric procedures: Review of the Bariatric outcomes Longitudinal Database. Surg Obes Relat Dis. 2014;10(3):502-7. doi: 10.1016/j.soard.2013.07.018. Epub 2013 Aug 29.

29. Prachand VN, Alverdy JC. Gastroesophageal reflux disease and severe obesity: Fundoplication or bariatric surgery? World J Gastroenterol. 2010;16(30):3757-61. 